Pesq. Vet. Bras. 37(6):613-620, junho 2017 DOI: $10.1590 / \mathrm{S} 0100-736 \mathrm{X} 2017000600014$

\title{
Immunohistochemical, lectin histochemical and ultrastructural studies of canine transmissible venereal tumor in Brazil ${ }^{1}$
}

\author{
Mariana B. Mascarenhas ${ }^{2 *}$, Paulo V. Peixoto ${ }^{3}$, Regina R. Ramadinha ${ }^{4}$, Anibal \\ G. Armien ${ }^{5}$, Samay Z. Costa ${ }^{2}$, Ileana C. Miranda ${ }^{2}$, Vivian A. Nogueira ${ }^{6}$ \\ and Ticiana N. França ${ }^{6}$
}

\begin{abstract}
Mascarenhas M.B., Peixoto P.V., Ramadinha R.R., Armién A.G., Costa S.Z., Miranda I.C., Nogueira V.A. \& França T.N. 2017. Immunohistochemical, lectin histochemical and ultrastructural studies of canine transmissible venereal tumor in Brazil. Pesquisa Veterinária Brasileira 37(6):613-620. Programa de Pós-Graduação em Medicina Veterinária, Universidade Federal Rural do Rio de Janeiro, BR-465 Km 7, Seropédica, RJ 23890-000, Brazil. E-mail: mm.bezerra@yahoo.com

Canine transmissible venereal tumor (CTVT) is a naturally occurring contagious round-cell neoplasia, with poorly understood origin and transmission. This study aims to further investigate the tumor nature through immunohistochemistry, lectin histochemistry and transmission electron microscopy (TEM) analysis, and to provide support for diagnostic and differential diagnoses of CTVT. Immunohistochemistry was performed in 10 genital and six exclusively extragenital tumors, which were previously diagnosed by citology and histopathology. CTVT samples were incubated with biotinylated antibodies to specific membrane and cytoplasmic antigens (anti-lysozyme, anti-macrophage, anti-vimentin, anti-CD18, monoclonal anti-CD117, monoclonal anti-CD3, polyclonal anti-CD117, polyclonal CD3 and anti-CD79a), followed by the avidin-biotin-peroxidase complex technique. The lectins Con A, DBA, SBA, PNA, UEA-1, WGA, sWGA, GSL, JSA, PSA, PHA-L, PHA-E and RCA were additionally tested in four genital CTVTs and TEM was performed in eight genital tumors. The anti-vimentin antibody revealed strong immunoreactivity to neoplastic cells in all the assessed samples (16/16). The polyclonal anti-CD3 antibodies showed moderate to strong immunoreactivity in fourteen (14/16) and the polyclonal anti-CD117 in fifteen cases $(15 / 16)$. There was no immunoreactivity to anti-lysozyme, anti-macrophage, anti-CD18, monoclonal anti-CD117, monoclonal anti-CD3 and anti-CD79a antibodies. At lectin histochemistry, it was observed strong staining of tumor cells to Con-A, PHA-L and RCA. There was no histopathological and immunoreactivity differences between genital and extragenital CTVTs. These findings do not support the hypothesis of histiocytic origin of CTVT. In contrast, the lectin histochemical results were similar to cells from lymphoid/ myeloid origin.
\end{abstract}

INDEX TERMS: Canine transmissible venereal tumor, CTVT, immunohistochemistry, lectin histochemistry, ultrastructural, dog, pathology.

\footnotetext{
${ }^{1}$ Received on November 10, 2016.

Accepted for publication on November 29, 2016.

Part of the first author's Doctor Dissertation.

${ }^{2}$ Programa de Pós-Graduação em Medicina Veterinária, Instituto de Veterinária, Universidade Federal Rural do Rio de Janeiro (UFRRJ), BR-465 Km 7, Seropédica, RJ 23890-000, Brazil. *Corresponding author: mm.bezerra@yahoo.com

${ }^{3}$ Departamento de Nutrição e Pastagem, Instituto de Zootecnia, Universidade Federal Rural do Rio de Janeiro (UFRRJ), BR-465 Km 7, Seropédica, RJ 23890-000, Brazil.
}

\footnotetext{
${ }^{4}$ Departamento de Medicina e Cirurgia Veterinária, Instituto de Veterinária, Universidade Federal Rural do Rio de Janeiro (UFRRJ), BR-465 Km 7, Seropédica, RJ 23890-000, Brazil.

${ }^{5}$ Veterinary Diagnostic Laboratory, Department of Veterinary Population Medicine, College of Veterinary Medicine, University of Minnesota, 1333 Gortner Avenue, Saint Paul, MN 55108, USA.

${ }^{6}$ Departamento de Epidemiologia e Saúde Pública, Instituto de Veterinária, Universidade Federal Rural do Rio de Janeiro (UFRRJ), BR-465 Km 7, Seropédica, RJ 23890-000, Brazil.
} 
RESUMO-- [Estudos imuno-histoquímico, lectino-histoquímico e ultraestrutural do Tumor Venéreo Transmissível Canino no Brasil.] 0 Tumor Venéreo Transmissível Canino (CTVT) é uma neoplasia de células células redondas, contagiosa, com origem e transmissão ainda mal compreendidas. Com a finalidade de aprofundar a investigação sobre a natureza (origem) do TVTC, bem como fornecer subsídios para o estabelecimento do diagnóstico e diagnóstico diferencial, realizaram-se avaliações imuno-histoquímica, lectino-histoquímica e ultraestrutural de TVTC(s). A avaliação imuno-histoquímica foi feita em 10 TVTCs genitais e em 6 exclusivamente extragenitais previamente diagnosticados através de citologia e da histopatologia. Os TVTCs foram testados para reagentes específicos de antígenos de membrana e citoplasmáticos (anti-lisozima, anti-macrófago, anti-vimentina, anti-CD18, anti-CD3, anti-CD79, anti-CD117) com utilização da técnica complexo avidina-biotina-peroxidase. Adicionalmente, foram utilizadas as lectinas Con A, DBA, SBA, PNA, UEA-1, WGA, sWGA, GSL, SJA, PSA, PHA-L, PHA-E e RCA em quatro TVTCs genitais. Microscopia eletrônica foi realizada em oito TVTC genitais. Em 100\% dos tumores testados (16/16) com anticorpo anti-vimentina (mono e policlonal) houve forte imuno-reatividade. Não houve reatividade para os anticorpos anti-lisozima, anti-macrófago, anti-CD18, anti-CD3, anti-CD79a e anti-CD117 quando empregamos anticorpos monoclonais, entretanto, com a utilização de anticorpos policlonais verificou-se marcação dos tumores com os anticorpos anti-CD3 e anti-CD117. Na avaliação lectino-histoquímica foi verificada forte marcação das células tumorais com Con-A, PHA-L e RCA. Não houve diferença histopatológica e de imuno-reatividade entre os TVTCs genitais e extragenitais. Estes achados não corroboram com a hipótese da origem histiocítica do CTVT (ausência de reatividade dos anticorpos anti-lisozima, anti-macrófago e anti-CD18), entretanto, os resultados da avaliação lectino-histoquímica foram em parte similares aos obtidos quando células de origem linfóide/mielóide (ConA, PHA-L e RCA) foram analisadas (Gimeno et al. 1995).

TERMOS DE INDEXAÇÃO: Tumor venéreo transmissível canino (TVTC), imuno-histoquímica, lectino-histoquímica, microscopia eletrônica, cão, patologia.

\section{INTRODUCTION}

Canine transmissible venereal tumor (CTVT) is a naturally occurring contagious round-cell neoplasia, located mainly on the external genital mucosa of both male and female dogs (Cohen 1985). CTVT is a clonal cell lineage that spreads within the domestic dog population by the allogeneic transfer of living cancer cells, usually during coitus (Murchison et al. 2014). This tumor has been historically called by other names, such as Sticker`s sarcoma (Sticker 1904), venereal granuloma, canine condyloma, contagious lymphoma (Vermooten 1987) and transmissible venereal sarcoma (Yang 1988). The biological features of CTVT are unique and no similar neoplasia is found in other domestic animal species. The uncertain nature of this tumor has been a matter of controversy for decades and still remains an unsolved question (Gimeno et al. 1995). The exact cyto- genetic origin of this tumor remains not clear. Mozos et al. (1996) and Marchal et al. (1997) demonstrated that CTVT cells express macrophage markers, suggesting that the tumor has a histiocytic origin, while others, have not confirmed these findings through immunohistochemical studies (Goldschmidt \& Hendrick 2002, Gross et al. 2005, Mascarenhas et al. 2014). Clinically, this tumor appears as a solitary, red, friable, often "cauliflower-like mass" (Vermooten 1987, Rogers 1997, Papazoglou et al. 2001). Extragenital occurrence of CTVT without genital lesions has been reported in oral (Bright et al. 1983, Ramadinha et al. 1993, Morrison 1998) and nasal cavities (Ndiritu et al. 1977, Bright et al. 1983, Morrison 1998, Papazoglou et al. 2001), conjunctiva and eye (Barron et al.1963), skin and subcutis (Nielsen \& Kennedy 1990), tonsils (Theilen \& Madewell 1987) and anal mucosa (Batamuzi \& Bittegeko 1991). In these cases, it might be difficult to rule out differential diagnoses, such as lymphomas, histiocytomas, poorly differentiated mast cell tumors, amelanotic epithelioid melanomas, and poorly differentiated carcinomas (Mozos et al. 1996, Lorimier \& Fan 2007). The purpose of the present study was to go deeper in the immunohistochemical, lectin histochemical and transmission electron microscopy (TEM) analysis of spontaneous genital and extragenital CTVT, in order to support the diagnosis and differential diagnosis of this neoplasm and provide additional information about its origin.

\section{MATERIALS AND METHODS}

Tissue samples. Neoplastic tissue was collected from 16 dogs of different breeds, ages and genders. In 10 dogs, tumors were located in the external genital mucosa, while in six dogs the tumors had an extragenital location (three in the skin, two in the oral cavity and one in the nasal cavity). Tissue samples were fixed in $10 \%$ buffered formalin and embedded in paraffin. All tumors were diagnosed as CTVT after clinical, cytopathologic and histopathologic evaluation. In addition, the tumors had a complete clinical remission after treatment with vincristine.

Immunohistochemistry. The streptavidin-biotin peroxidase method was used for immunohistochemical study. Tissue sections of 16 CTVTs were deparaffinized and rehydrated. Endogenous peroxidase activity was blocked by treatment with $3 \% \mathrm{H} 2 \mathrm{O} 2$ for 30 minutes at room temperature. After microwave treatment with citrate buffer, $\mathrm{pH} 6$, tissue sections were incubated with $5 \%$ powdered milk (Molico) for 30 minutes at room temperature. Primary antibodies used in this study and their specific dilutions are summarized in Table 1 and Table 2. After rinsing in phosphate-buffered saline (PBS), a streptavidin-immunoperoxidase staining procedure (Dako) was used for immunolabeling. The immunoreactions was observed with 3,3'diaminobenzidine substrate (Dako). Sections were then counterstained with Harris hematoxylin. In addition to polyclonal antibody, we performed IHC using monoclonal antibody to detect CD3 and CD117 antigens on tumors from 5 dogs (Table 1). Immunohistochemical staining was performed using a peroxidase-based polymer system (Envision TM-HRP; Dako, Carpinteria, California, USA). Primary antibodies included CD3 (1:25; monoclonal; Dako), CD117 (1:100, monoclonal; Dako). Immunopositive reactions were visualized with the chromogen, 3-amino-9-ethylcarbazole, and sections were counterstained with Harris hematoxylin. Positive immunohistochemical controls for each one of the antibodies were used. The immunoreactivity was visually graded as negative $(-)$, weak $(+)$, moderate $(++)$ and strong $(+++)$. 
Lectin Histochemistry. The lectin-histochemical study was carried out using four genital CTVTs. The lectins used were Concanavalia ensiformis agglutinin (Con A; a-d-Man; a-d-Glc-specific), Dolichos biflorus agglutinin (DBA; a-d-Gal-Nac-specific), Glycine max agglutinin (SBA; a-d-GalNac; b-Gal-specific), Arachis hypogaea agglutinin (PNA; b-d-Gal/(1-3)GalNAc-specific), Ricinus communis agglutinin-I (RCA-I; b-d-Gal-specific), Ulex europaeus agglutinin-I (UEA-1; a-L-Fuc-specific), Triticum vulgaris agglutinin (WGA; a-d-GlcNAc/NeuNAc-specific), Succinyl-WGA (sWGA), Griffonia (Bandeiraea) simplicifolia (GSL), Sophora japonica (SJA), Pisum sativum (PSA), Phaseolus vulgaris (PHA-L e PHA-E), Lens culinaris or L. esculenta (LCA) (Lectin Kit Biotinylated BK 1000 e 2000, Vector Laboratories Inc., Burlingame, CA, USA). The slides were deparaffinized in xylol and hydrated in decreasing concentrations of alcohol. The inactivation of endogenous peroxidase was carried out with 3\% hydrogen peroxide in distilled water for 30 minutes, and the recovery with heat, using a buffer solution of $10 \mathrm{mM}$ citrate $(\mathrm{pH} 6.0)$ in a bain-marie $\left(100^{\circ} \mathrm{C}\right)$ for 60 minutes. To reduce the unspecific bonds (background), the sections were treated with 5\% skimmed milk (Molico) diluted with distilled water for 30 minutes. Immediately after, the lectins were applied in a dilution of $5 \mu \mathrm{g} / \mathrm{ml}$ in PBS (phosphate buffered saline) $\mathrm{pH}$ 7.4, except for Con-A, which was applied in a dilution of $1 \mu \mathrm{g} / \mathrm{ml}$. The slides were then incubated in a humid chamber at $4^{\circ} \mathrm{C}$ for $12-14$ hours overnight. After this period, each slide and its respective lectin were washed individually with distilled water and PBS. Streptavidin (DAKO LSAB 2 kit, DAKO Corp., Carpinteria, CA, USA) was then applied for $20 \mathrm{~min}$ in a humid chamber. The development of the sections was carried out with diaminobenzidine (DAB) chromogen (DAKO) for $5 \mathrm{~min}$ or until the section became brown. The sections were then counterstained with Harris hematoxylin for 30 seconds, mounted in Entellan (Merck, Darmstadt, Germany Sigma Chemical Co., Saint Louis, USA) and observed under an optical microscope. Negative control using PBS solution was used.

TEM. For ultrastructural examination, small formalin fixed fragments of neoplastic tissue from 8 dogs were postfixed in $0.166 \mathrm{M}$ cacodylate-buffered, $3 \%$ glutaraldehyde with $1 \%$ tannic acid solution (Electron Microscopy Sciences), followed by a second postfixation treatment in 1\% osmium tetroxide (Electron Microscopy Sciences). Using a graded series of ethyl alcohol, 1.0mm3 tissue blocks were dehydrated and then embedded in Embed Embedded samples were trimmed and sectioned on a Leica UC6 Ultramicrotome (Leica Microsystems, Wetzlar, Germany). Thin sections $(60-90 \mathrm{~nm})$ were collected on 100-mesh copper grids (Electron Microscopy Sciences), and then grids were stained with $5 \%$ uranyl acetate for 20 minutes and Sato's lead citrate for 6 minutes. We examined samples with a JEOL 1200 EX II Transmission Electron Microscope (JEOL Ltd, Tokyo, Japan) and obtained images using a Veleta $2 \mathrm{~K}-2 \mathrm{~K}$ camera with iTEM software (Olympus SIS, Munster, Germany).

\section{RESULTS}

Based on histopathologic evaluation, tumors cells were large and round, often growing in sheath and rows in a delicate stroma. Neoplastic cells had large, round vesicular

Table 1. Antibodies, dilutions, incubation and antigen recovery method used in immunohistochemical caracterization of canine transmissible venereal tumor

\begin{tabular}{|c|c|c|c|c|c|}
\hline Antibody & Clone & Brand & Dilution & Incubation & Treatment \\
\hline Vimentin & V9 & Diagnostic Biosystem & $1 / 200$ & overnight & micro*. 6 minutos + citrato \\
\hline Lysozyme & $* *$ & Zymed / Invitrogen & $1 / 100$ & overnight & micro*. 6 minutos + citrato \\
\hline CD79a & HM57 & Santa Cruz Biotechnology & $1 / 20$ & overnight & micro*. 6 minutos + citrato \\
\hline CD3 polyclonal & $* *$ & Spring Bioscience & $1 / 100$ & overnight & micro* 6 minutos + citrato \\
\hline CD3 monoclonal & CP215 & Biocare Medical & $1 / 25$ & 45 minutes & $\begin{array}{c}\text { Heat retrieval } \\
\text { (pressure cooker); } \\
\text { pH } 9 \text { retrieval solution (Dako) }\end{array}$ \\
\hline CD18 & CA16 3C10 & University of California & $1 / 20$ & overnight & micro* 6 minutos + citrato \\
\hline CD117 polyclonal & $* *$ & Diagnostic Biosystem & $1 / 200$ & overnight & micro* 6 minutos + citrato \\
\hline CD117 monoclonal & A4502 & Dako & $1 / 100$ & 45 minutes & $\begin{array}{c}\text { Heat retrieval } \\
\text { (pressure cooker); }\end{array}$ \\
\hline Anti-macrophage & LN-5 & Zymed / Invitrogen & $1 / 100$ & overnight & $\begin{array}{c}\text { Diva Decloaker solution (Biocare) } \\
\text { micro*. } 6 \text { minutos + citrato }\end{array}$ \\
\hline
\end{tabular}

* microwave, ** There is no clone.

Table 2. Immunohistochemical staining of CTVT using the antibodies listed in Table 1

CTVT 1 CTVT 2 CTVT 3 CTVT 4 CTVT 5 CTVT 6 CTVT 7 CTVT 8 CTVT 9 CTVT 10 CTVT 11 CTVT 12 CTVT 13 CTVT 14 CTVT 15 CTVT 16

\begin{tabular}{|c|c|c|c|c|c|c|c|c|c|c|c|c|c|c|c|c|}
\hline Vimentin & $(+++)$ & $(+++)$ & $(+++)$ & $(+++)$ & $(+++)$ & $(+++)$ & $(+++)$ & $(+++)$ & $(+++)$ & $(+++)$ & $(+++)$ & $(+++)$ & $(+++)$ & $(+++)$ & $(+++)$ & $(+++)$ \\
\hline Lysozyme & $(-)$ & $(-)$ & $(-)$ & $(-)$ & $(-)$ & $(-)$ & $(-)$ & $(-)$ & $(-)$ & $(-)$ & $(-)$ & $(-)$ & $(-)$ & $(-)$ & $(-)$ & $(-)$ \\
\hline CD79a & $(-)$ & $(-)$ & $(-)$ & $(-)$ & $(-)$ & $(-)$ & $(-)$ & $(-)$ & $(-)$ & $(-)$ & $(-)$ & $(-)$ & $(-)$ & $(-)$ & $(-)$ & $(-)$ \\
\hline $\begin{array}{l}\text { CD3 } \\
\text { polyclonal }\end{array}$ & $(+)$ & $(+)$ & $(++)$ & $(+++)$ & $(++)$ & $(++)$ & $(++)$ & $(++)$ & $(-)$ & $(++)$ & $(+++)$ & $(++)$ & $(++)$ & $(++)$ & $(-)$ & $(++)$ \\
\hline $\begin{array}{l}\text { CD3 } \\
\text { monoclonal }\end{array}$ & $(-)$ & & & & & & & & & & $(-)$ & $(-)$ & $(-)$ & & $(-)$ & \\
\hline CD18 & $(-)$ & $(-)$ & $(-)$ & $(-)$ & $(-)$ & $(-)$ & $(-)$ & $(-)$ & $(-)$ & $(-)$ & $(-)$ & $(-)$ & $(-)$ & $(-)$ & $(-)$ & $(-)$ \\
\hline $\begin{array}{l}\text { CD117 } \\
\text { polyclonal }\end{array}$ & $(+++)$ & $(-)$ & $(+++)$ & $(+++)$ & $(+++)$ & $(+++)$ & $(+++)$ & $(+++)$ & $(+++)$ & $(+++)$ & $(+++)$ & $(+++)$ & $(+++)$ & $(+++)$ & $(+++)$ & $(+++)$ \\
\hline $\begin{array}{l}\text { CD117 } \\
\text { monoclonal }\end{array}$ & $(-)$ & & & & & & & & & & & $(-)$ & $(-)$ & $(-)$ & & $(-)$ \\
\hline $\begin{array}{l}\text { Anti- } \\
\text {-macro phage }\end{array}$ & $(-)$ & $(-)$ & $(-)$ & $(-)$ & $(-)$ & $(-)$ & $(-)$ & $(-)$ & $(-)$ & $(-)$ & $(-)$ & $(-)$ & $(-)$ & $(-)$ & $(-)$ & $(-)$ \\
\hline
\end{tabular}

Staining intensity: ( )not done, (-)negative, $(+)$ weak, $(++)$ moderate, $(+++)$ strong. 
nuclei with single prominent nucleolus. The cytoplasm was slightly granular, vacuolated, and eosinophilic. The degree of intratumoral perivascular infiltration by mature lymphocytes, plasma cells, neutrophils and macrophages was quite variable. Mitotic figures were plentiful (Fig.1).

Immunohistochemical results are summarized in Table 2. All CTVTs analyzed were negative for anti-lysozyme, anti-macrophage, anti-CD18 antigen and anti-CD79a (Table 2). Infiltrating macrophages and neutrophils showed intense immunoreactivity to anti-lysozyme, anti-macrophage and anti-CD18, thus serving as an internal positive control (Fig.2, 3, 4). Immunoreactivity to vimentin, was intense in the cytoplasm of more than $90 \%$ of the tumors cells of all CTVT analyzed (Fig.5, Table 2). Tumors were negative for the monoclonal anti-CD3 and monoclonal anti-CD117 antibodies. However, for the anti-CD117 polyclonal type, only one CTVT genital did not express immunoreactivity, while the other 15 tumors showed strong staining (Fig.6). Fourteen out of 16 CTVT showed immunoreactivity to polyclonal anti-CD3 and 6 of them showed an intense staining pattern presented in the perinuclear region (Fig.7).

The lectin histochemical analysis, neoplastic cells exhibit strong reaction for lectins PHA-L, ConA and RCA (Fig.8 and 9), moderate staining for PHA-E and UEA and weak reaction for LCA, SBA and PSA. All CTVTs were negative for SJA, PNA, SWGA, WGA and GSL.

At ultrastructural evaluation, CTVT was composed of a monomorphic population of round cells with a 1:2 to $1: 3$ nucleus/cytoplasm ratio. CTVT cells present a fine heterochromatic nucleus, varying from round with slight indentation to reniform, with prominent compact nucleolus (Fig.10). The cytoplasm has numerous small round mito-
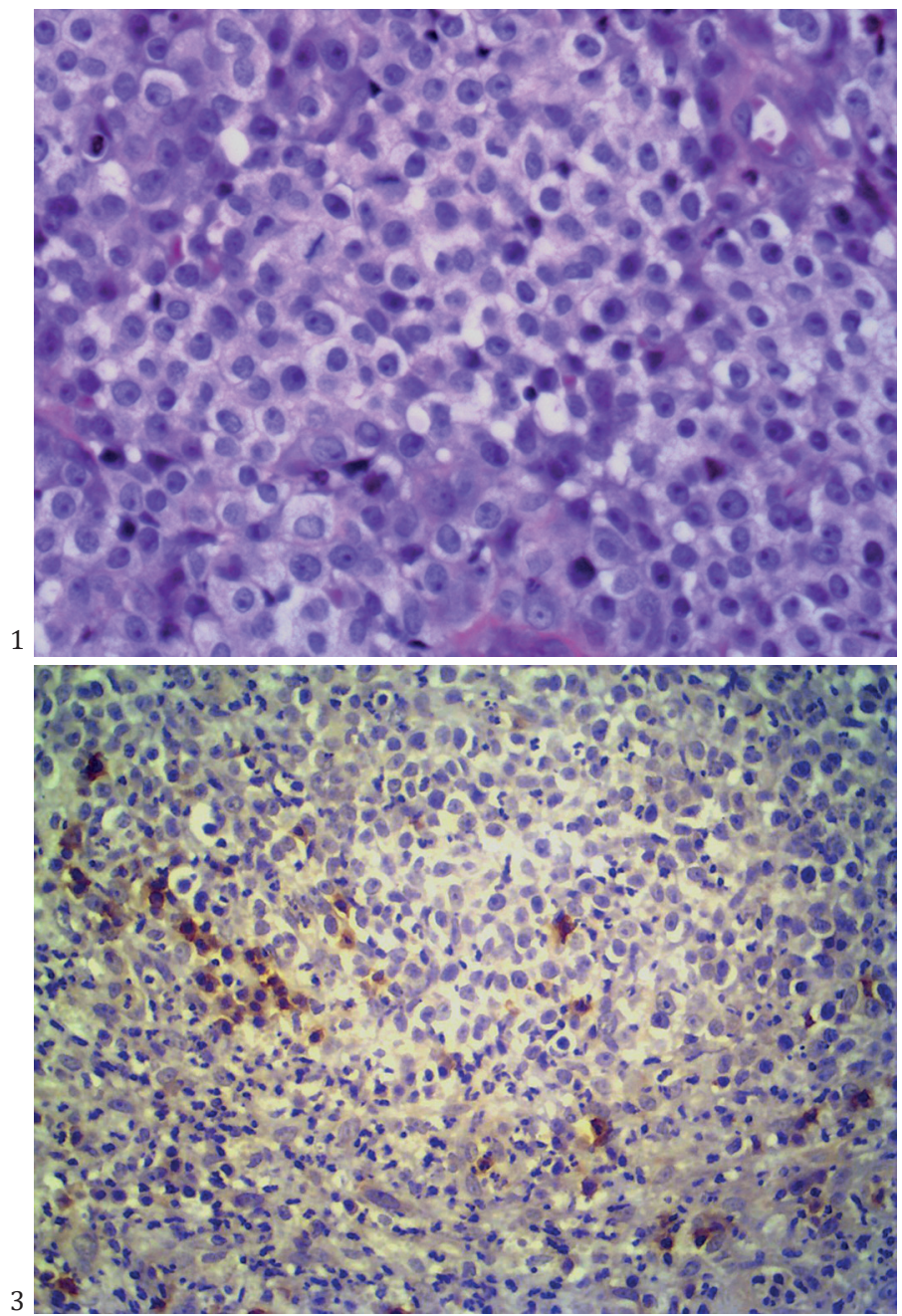

Fig.1. Genital CTVT (Dog 5). Tumor cells were large and round; they had large, round vesicular nuclei with single prominent nucleolus; the cytoplasm vacuolated and eosinophilic, mitotic figures were frequent. HE, obj.40x.

Fig.3. Genital CTVT (Dog 2). Notice staining of numerous infiltrating macrophages and unreactivity tumor cells for human monoclonal antibody anti-macrophage. Streptavidin-biotin peroxidase method, Harris's hematoxilin counterstain, obj.20x.
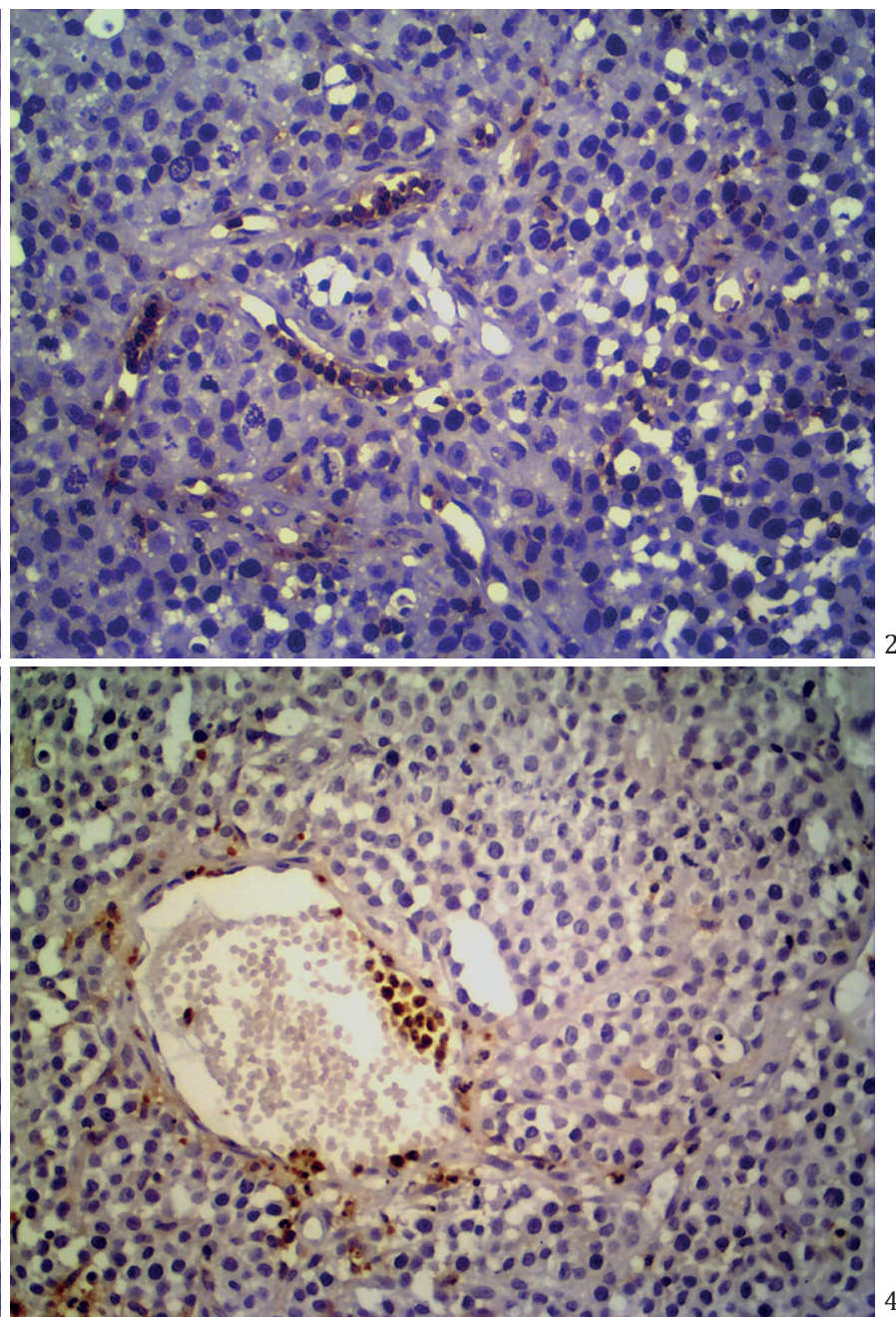

Fig.2. Genital CTVT (Dog 6). Unreactive tumor cells for human polyclonal antibody lysozyme and an immunoreactivity of infiltrating macrophages and neutrophils. Streptavidin-biotin peroxidase method, Harris's hematoxilin counterstain, obj.20x.

Fig.4. Genital CTVT (Dog 4). Staining of numerous infiltrating macrophages and neutrophils and unreactivity tumor cells for anti-CD18 antigen. Streptavidin-biotin peroxidase method, Harris's hematoxilin counterstain, obj.20x. 

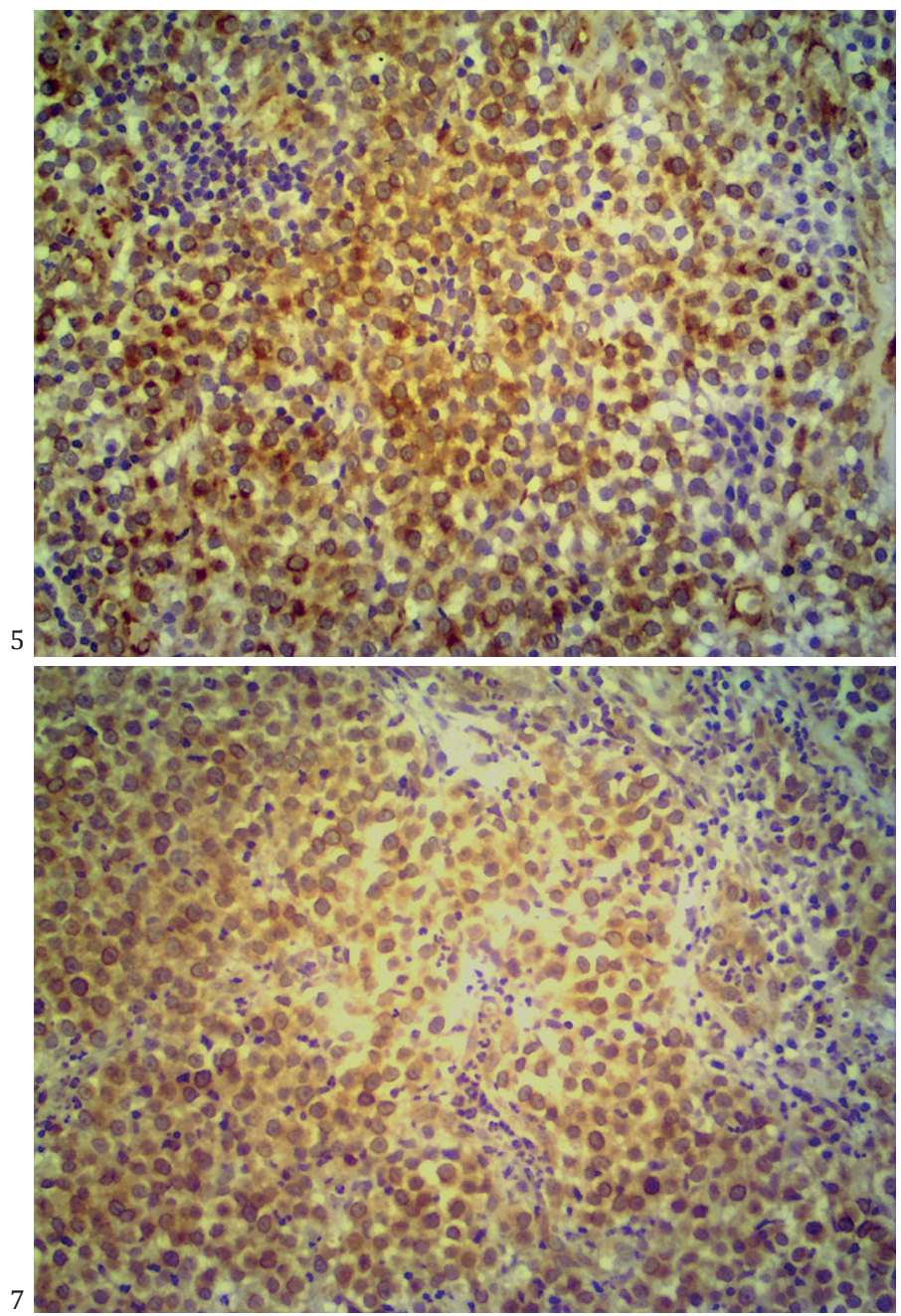

Fig.5. Genital CTVT (Dog 1). Majority of tumor cells show vimentin immunoreactivity. Streptavidin-biotin peroxidase method, Harris's hematoxilin counterstain, obj.20x.

Fig.7. Genital CTVT (Dog 3). Staining of tumors cells for human polyconal antibody CD3. Notice intense staining present in the perinuclear region. Streptavidin-biotin peroxidase method, Harris's hematoxilin counterstain, obj.20x.

chondria, small lysosomes, Golgi system, and occasionnaly a centriolus (Fig.11). In all samples, small number of plasma cells, lymphocytes, neutrophils and macrophages were observed.

\section{DISCUSSION}

The 16 CTVTs studied exhibited light and TEM (Hill et al. 1984) morphological features that did not differ from those described in the literature (Nielsen \& Kennedy 1990, Scott et al. 2001, Gross et al. 2005, Harmelin et al. 2002). Also, no morphological differences were found between genital and extragenital CTVTs.

However, several differences were observed in the immunohistochemical analysis of the tumors previously described by Mozos et al. (1996) and Marchal et al. (1997). All CTVT in this study were lysozyme-negative, the same found by Mascarenhas et al. (2014), whereas Mozos et al. (1996) found immunoreactivity in $40 \%$ of cases and Marchal et al. (1997) in $100 \%$ of the tumors. It is important to remem-
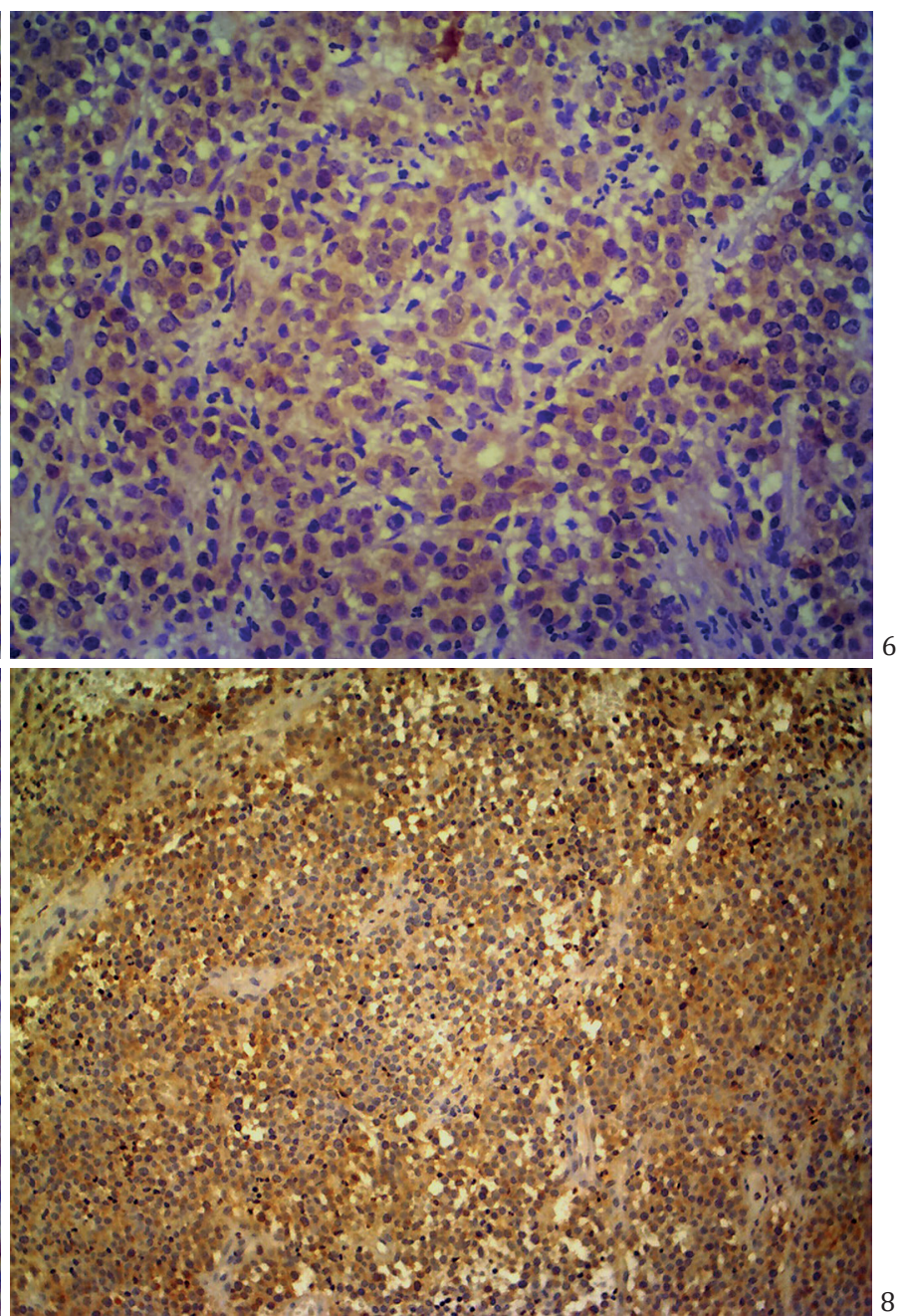

Fig.6. Genital CTVT (Dog 4). Staining of tumors cells for human polyconal antibody CD117. Streptavidin-biotin peroxidase method, Harris's hematoxilin counterstain, obj.20x.

Fig.8. Genital CTVT (Dog 4). PHA-L lectin binding to neoplastic cells. Streptavidin-peroxidase method, Harris's hematoxilin counterstain, obj.20x.

ber that infiltrating macrophages and neutrophils showed intense immunoreactivity, which may cause confusion in the interpretation if they are mistaken with the CTVT cells on light microscopy. In this study, macrophages and neutrophils were strongly immuno-reactive for lysozyme; at an initial and less accurate analysis, these cells were mistaken with tumor cells. Additionally, tumors from distinct geographic regions worldwide feature unique chromosomal patterns of gain and loss, arguing for local lineages (Von Holdt \& Ostrander 2006). Cytogenetic studies show that CTVTs lacks subclonal heterogeneity, despite thousands of rearrangements, copy-number changes, and retrotransposon insertions (Murchison at al. 2014). The subclonal heterogeneity leading from local lineages may explain the difference in protein expression in tumor cells from different geographic regions. Adequate fixation is essential for immunohistochemistry to preserve antigenicity (Ramos-Vara et al. 2008). An inadequate fixation could explain the loss of expression of lysozyme by the tumors cells, al- 
though infiltrating macrophages and neutrophils showed an intense immunoreactivity to this antibody that served as an internal positive control and excluded this possibility.

The expression of lysozyme by CTVT has been used to support the hypothesis that this tumor is of histiocytic origin (Mozos et al. 1996, Marchal et al. 1997), although in dogs lysozyme is not considered a reliable marker for histiocytomas (Sandusky et al. 1987, Marchal et al. 1997) and histiocytic disorders (Moore 1986). Some authors had excluded this antibody from the panel of immune markers

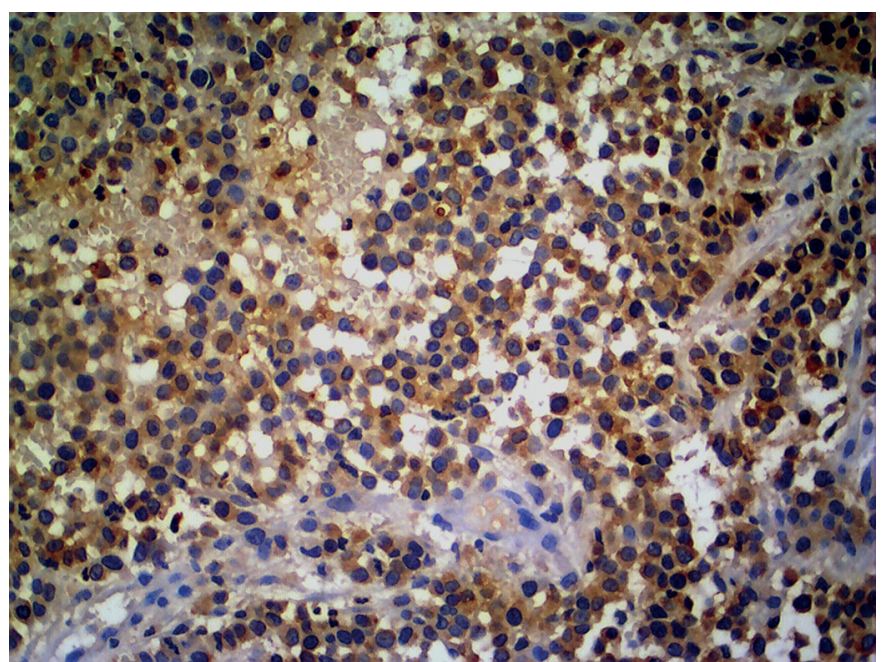

Fig.9. Genital CTVT (Dog 4). Con-A lectin binding to neoplastic cells. Streptavidin-peroxidase method, Harris's hematoxilin counterstain, obj.20x.

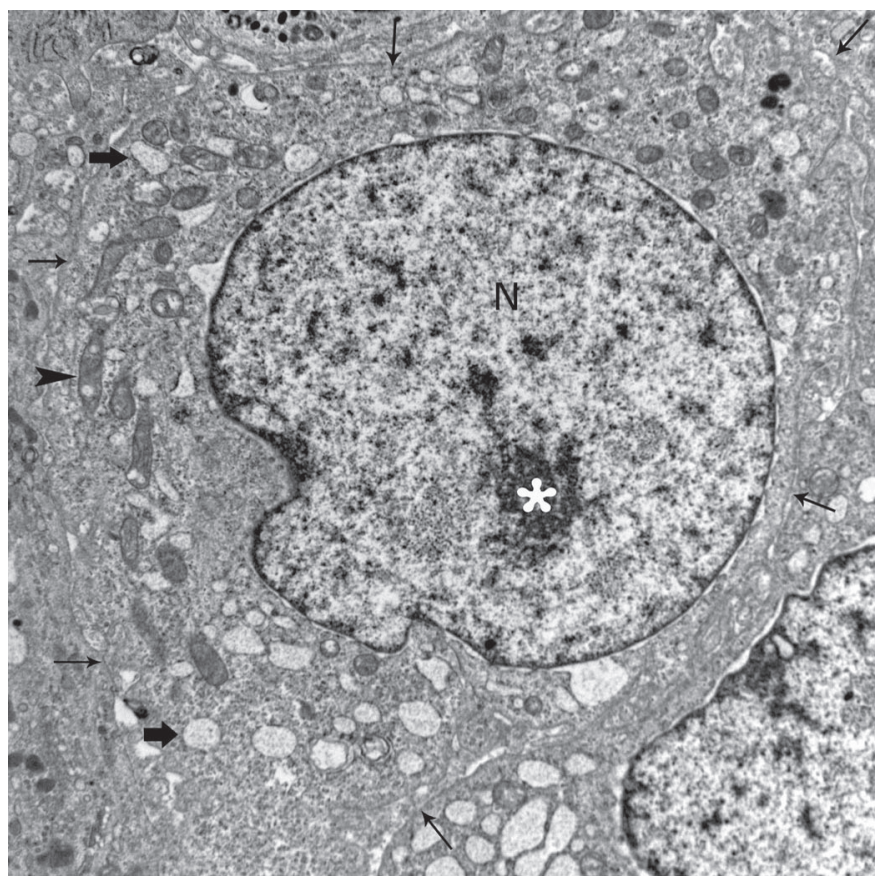

Fig.10. Electron Microscopy photograph of a canine transmissible venereal tumor cell, TVT Cell presenting a fine heterochromatic nucleus (N), prominent nucleolus (asterisk); the cytoplasm has numerous mitochondria (arrowhead) and lysosomes (fat arrow). The TVT cell plasma membrane is demarcated with small arrows.

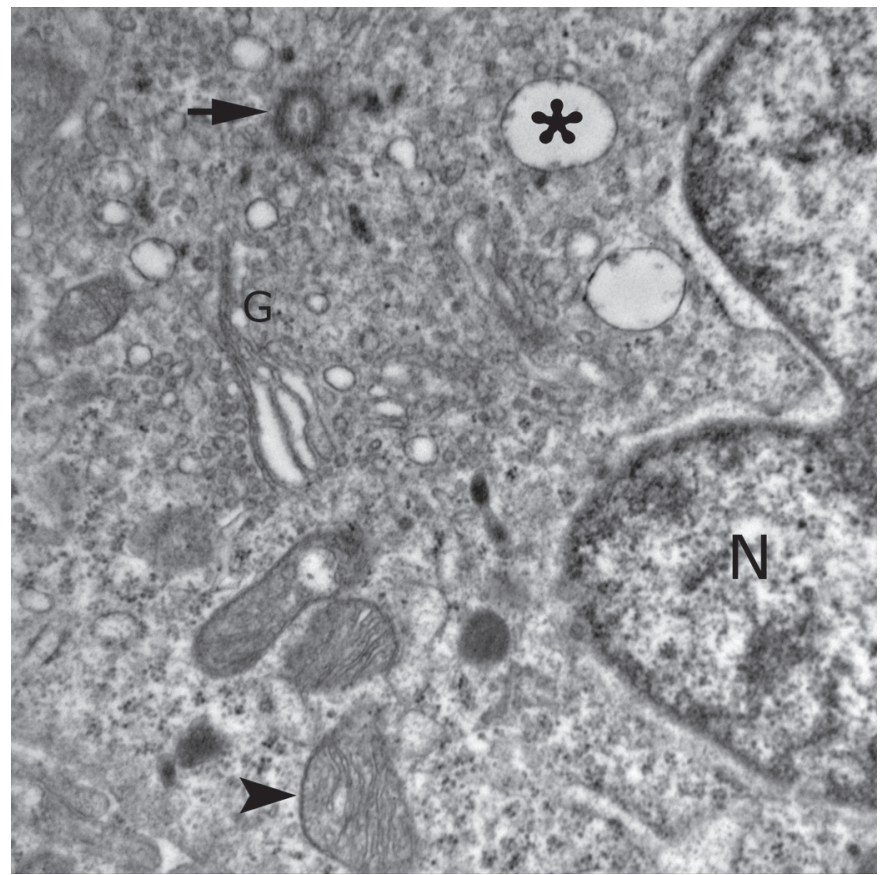

Fig.11. Electron Microscopy photograph of a canine transmissible venereal tumor cell. High magnification of a TVT Cell. Note a heterochromatic nucleus (N), mitochondria (arrowhead) and lysosomes (asterisk), Golgi system (G), and centriolus (arrow).

for histiocytes due to its inconsistent results (Morris et al. 2002). In this study, anti-human-macrophage is an additional macrophage marker that was not expressed by any of the CTVTs, but showed intense immunoreactivity to infiltrating macrophages in the tissue. Similarly, all tumor cells analyzed were negative for CD18. Although it is known as a broad leukocyte marker, histiocytic tumors are strongly immunoreactive to this antibody (Lorimier \& Fan 2007). Currently, CD18-positive and CD3- and CD79-negative stainings are used to rule out lymphoid origin, and these markers are considered the most reliable to identifying cell of histiocytic origin (Affolter \& Moore 2002). These results (negative for lysozyme, anti-human macrophage and CD18) do not support the histiocytic origin of CTVTs.

All CTVTs of our series showed intense cytoplasmic immunoreactivity to vimentin in more than $90 \%$ of all tumors cells. These results are in agreement with those previously reported (Sandusky et al. 1987, Mozos et al. 1996, Marchal et al. 1997, Mascarenhas et al. 2014). Vimentin is an intracellular protein (intermediary filament) found mainly in mesenchymal cells. This supports the idea of mesenchymal origin because CTVT cells retain vimentin like macrophages and lymphocytes.

All tumors tested in the current study were negative for monoclonal anti-CD117. CD117 (KIT) is a type III receptor tyrosine kinase operating in cell signal transduction in several cell types. KIT deficiency due to hereditary nonsense/ missense mutations leads to disruption of KIT dependent functions such as erythropoiesis, skin pigmentation, fertility, and gastrointestinal motility. Conversely, pathologic activation of KIT through gain-of-function mutations leads to neoplasia of KIT-dependent and KIT-positive cell types 
at least in three different systems: mast cells/myeloid cells - mastocytosis/acute myeloid leukemia, germ cells - seminoma, and Cajal cells - gastrointestinal stromal tumors (GISTs) (Miettinen \& Lasota 2005). In mouse, this antibody is positive in early T-lymphoblastic lymphoma (CD3+, CD5+, CD43+, TdT+, CD117+) (Rehg et al. 2012). Interestingly, when we used the polyclonal anti-CD117, except for one case, all tumors tested showed moderate to strong cytoplasmic labeling for the polyclonal CD117.

Even though all tumors were negative for monoclonal anti-CD3 and anti-CD79a, we did not exclude the possibility of lymphoid/myeloid origin. It is also not uncommon for human T-cell lymphomas, for example, to lose one or more of the four (CD2, CD3, CD5, CD7) pan-T-cell antigens (Rehg et al. 2012). Moreover, the immunohistochemistry allows the classification of mouse T-cell lymphoma and, in some instances, T-cell lymphomas lack CD3 expression (Rehg et al. 2012). Furthermore, 14 out of 16 tumors showed immunoreactivity when we used a polyclonal anti-CD3 (Spring Bioscience), and in six CTVTs we observed a strong intracytoplasmic perinuclear staining. According to Ramos-Vara (2014), the CD3 antibody is considerate a highly specific marker for $\mathrm{T}$ cells and it is first detectable in early thymocytes. Its appearance probably represents one of the earliest signs of commitment to the T cell lineage. In cortical thymocytes the antigen is predominantly present as an intracytoplasmic constituent. It appears subsequently (at the medullary thymocyte stage) on the $\mathrm{T}$ cell surface. Maturation is defined by the loss of perinuclear CD3 positivity and the acquisition of surface CD3 (Swerdlow et al. 1988). Like immature lymphocytes T, when our CTVTs were tested with the polyclonal CD3, neoplastic cells expressed CD3 as an intracytoplasmatic constituent. The polyclonal CD3 antibody, commonly used in immunohistochemistry, targets both the cytoplasmic epsilon unit and the surface units of the CD3 complex (Rehg et al. 2012).

As our findings with the antibodies polyclonal anti-CD117 and polyclonal anti-CD3 were different from those described in the literature (Marchal et al. 1997, Ramos-Vara, 2014), we decided to try the monoclonal antibodies. The differences found in the results of polyclonal and monoclonal CD117 and CD3 antibodies might be due to the ability of polyclonal antibodies to recognize numerous epitopes. Polyclonal antibodies are heterogeneous and recognize a host of antigenic epitopes, so the effect of change on a single or small number of epitopes is less likely to be significant. In contrast, monoclonal antibodies are produced by a single cell clone (Lipman et al. 2005). These polyclonal antibodies might identify an epitope in CTVT.

CTVTs were positive for the lectins PHA-L, Con-A and RCA. Ours results were very similar to those found by Gimeno et al. (1995). Nevertheless, WGA was negative in the current study. According to Ree et al. (1983) studies of a panel of 12 biotin-labeled lectins on reactive lymphoid tissue embedded in paraffin indicated that lymphoid cells, as well as free and tissue macrophage, stained variably with six (Con-A, LCA, PHA, PSA, RCA and WGA) of the 12 lectins, while the staining reaction of the remaining six lectins were either entirely negative (BSA, DBA, SBA, SJA, UEA) or only minimally positive (PNA). In addition, the lectin PHA has potent activity against erythrocytes agglutinating (PHA-E) and it is mitogenic for lymphocytes (PHA-L). PHA-L does not bind significantly to erythrocytes, although bind with high affinity to the T cells (Sell \& Costa 2000). It is well known that PHA and Con-A activate quiescent T lymphocytes by binding to the glycosylated receptor (Chilsont et al. 1984). The binding of lectins PHA-L and Con-A on CTVT cells is an additional evidence to the hypothesis of a possible lymphoid/myeloid origin of this tumor, which is in agreement with described by Gimeno et al. (1995) and Goldschmidt \& Hendrick (2002).

Although the CTVTs cells expressed the polyclonal CD3 and were positive for lectin PHA-L, ours results are not sufficient to support a lymphoid origin of this tumor. For diagnosis, there is still no good markers to identify CTVTs. Vimentin was the only one of the antibodies tested in this work that showed intense cytoplasmic immunoreactivity in more than $90 \%$ of all tumors cells but all mesenchymal tumors express this antibody.

Interestingly, ultrastructural features of all CTVTs examined were different from well differentiated macrophages and lymphocytes. Non-neoplastic, as well as neoplastic macrophages, present phagocytic activity, which is recognized by the present of phagolysosome with digested residues. This important activity was not a feature of CTVT cells. In contrast to non-neoplastic lymphocytes, CTVT cells have high cytoplasma:nucleus ratio and larger number of organelles. Nonetheless, these are not unequivocal morphological features that permits a distinction between non-neoplastic lymphocytes and CTVT cell.

Acknowledgements.- To CNPq, FAPERJ and CAPES for the financial support and scholarship. The authors thank Ms. Letícia Baptista Pinto for the technical assistance in the microtomy.

\section{REFERENCES}

Affolter V.K. \& Moore P.F. 2002. Localized and disseminated histiocytic sarcoma of dendritic cell origin in dogs. Vet. Pathol. 39:74-83.

Barron C.N., Saunders L.Z., Scibold H.R. \& Heath M.K. 1963. Intra-ocular tumors in animals. V. Transmissible venereal tumor of dogs. Am. J. Vet. Res. 24:1263-1269.

Batamuzi E.K. \& Bittegeko S.B.P. 1991. Anal and perianal transmissible venereal tumour in a bitch. Vet. Rec. 129:556.

Bright R.M., Gorman N.T., Probst C.W. \& Gorring R.L. 1983. Transmissible venereal tumor of the soft palate in a dog. J. Am. Vet. Med. Assoc. 183:893-895.

Chilsont O.P., Boylston A.W. \& Crumpton M.J. 1984. Phaseolus vulgaris phytohaemagglutinin (PHA) binds to the human $\mathrm{T}$ lymphocyte antigen receptor. EMBO J. 3(13):3239-3245.

Cohen D. 1985. The canine transmissible venereal tumor: a unique result of tumor progression. Adv. Cancer Res. 43:75-112.

Gimeno E.J., Massone A.R., Marino F.P. \& Idiart J.R. 1995. Intermediate filament expression and lectin histochemical features of canine transmissible venereal tumour. APMIS 103:645-650.

Goldschmidt M.H. \& Hendrick M.J. 2002. Tumors of the skin and soft tissue, p.45-117. In: Meuten D.J. (Ed.), Tumors in Domestic Animals. 4th ed. Iowa State Press, Ames. 
Gross T.L., Irhke P.J., Walder E.J. \& Affolter V.K. 2005. Skin diseases of the dog and cat: clinical and histopathologic diagnosis. 2nd ed. Blackwell Science, UK.

Harmelin A., Pinthus J.H., Friedmann-Morvinski D., Kaufman K. \& Brenner 0. 2002. Lack of MHC expression and retention of ultrastructural characteristics by xenograft transmissible venereal tumor cells in SCID mice. Vet. Immunol. Immunopathol. 86(3/4):245-249.

Hill D.L., Yang T.J. \& Wacht A. 1984. Canine Transmissible Venereal sarcoma: tumor cell and infiltrating leukocyte ultrastructure at different growth stages. Vet. Pathol. 21:39-45.

Lipman N.S., Jackson L.R., Trudel L.J. \& Weis-Garcia F. 2005. Monoclonal versus polyclonal antibodies: Distinguishing characteristics, applications, and information Resources. ILAR J. 46(23):258-268.

Lorimier L.P. \& Fan T.M. 2007. Canine Transmissible Venereal Tumor, p.799-802. In: Withrow S.J. \& MacEwen E.G. (Eds), Small Animal Clinical Oncology. 2nd ed. W.B. Saunders, Philadelphia.

Marchal T., Chabanne L., Kaplanski C., Rigal D. \& Magnol J.P. 1997. Immunophenotype of the canine transmissible venereal tumor. Vet. Immunol. Immunopathol. 57(1/2):1-11.

Mascarenhas M.B., Peixoto P.V., Ramadinha R.R., Yamasaki E.M., Costa S.Z., Driemeier D., Sonne L. \& França T.N. 2014. Immunohistochemical study of genital and extragenital forms of canine transmissible venereal tumor in Brazi. Pesq. Vet. Bras. 34(3):250-254.

Miettinen M. \& Lasota J. 2005. KIT (CD117): a review on expression in normal and neoplastic tissues, and mutations and their clinicopathologic correlation. Appl. Immunohistochem. Mol. Morphol. 13(3):205-219.

Moore P.F. 1986. Utilization of cytoplasmic lysozyme as a histiocytic marker in canine histiocytic disorders. Vet. Pathol. 23:757-776.

Morris J.S., McInnes E.F., Bostock D.E., Hoather T.M. \& Dobson J.M. 2002. Immunohistochemical and histopathologic features of 14 malignant fibrous histiocytomas from flat-coated retrievers. Vet. Pathol. 39:479-499.

Morrison W.B. 1998. Cancer in Dogs and Cats: medical and surgical management. Williams and Wilkins, Baltimore, p.795.

Mozos E., Méndez A., Gómez-Villamandos J.C., Martín de las Mulas J. \& Pérez J. 1996. Immunohistochemical characterization of canine transmissible venereal tumor. Vet. Pathol. 33:257-263.

Murchison E.P., Wedge D.C., Alexandrov L.B., Fu B., Martincorena I., Ning Z., Tubio J.M.C., Werner E.I., Allen J., De Nardi A.B., Donelan E.M., Marino G., Fassati A., Campbell P.J., Yang F., Burt A., Weiss R.A. \& Stratton M.R. 2014. Transmissible dog cancer genome reveals the origin and history of an ancient cell lineage. Science 343:437-440.

Ndiritu C.G., Mbogwa S.W. \& Sayer P.D. 1977. Extragenitally located transmissible venereal tumor in dogs. Mod. Vet. Pract. 58:940-946.

Nielsen S.W. \& Kennedy P.C. 1990. Tumor of the genital systems: transmissible venereal tumors of the dog, p.498-502. In: Moulton J.E. (Ed.), Tumors in Domestic Animals. California University Press, Berkeley.
Papazoglou L.G., Koutinas A.F., Plevraki A.G. \& Tontis D. 2001. Primary intranasal transmissible venereal tumor in the dog: a retrospective study of six cases. J. Vet. Med. A, Physiol. Pathol. Clin. Med. 48(7):391-400.

Ramadinha R.R., Ramadinha L.S. \& Kuner A. 1993. Tumor venéreo transmissível canino em cavidade oral sem lesão genital. Anais XV Congresso Brasileiro da Associação Nacional de Clínicos Veterinários de Pequenos Animais, Rio de Janeiro.

Ramos-Vara J.A., Kiupel M., Baszler T., Bliven L., Brodersen B., Chelack B., Czub S., Piero F.D., Dial S., Ehrhart E.J., Grahan T., Manning L., Paulsen D., Valli V.E. \& West K. 2008. Suggested guidelines for immunohistochemical techniques in veterinary diagnostic laboratories. J. Vet. Diagn. Invest. 20:393-413.

Ramos-Vara J.A. Homepage. Disponível em <http://web.ics.purdue. edu/ jramosva/index.htm> Acesso em 24 fev. 2014.

Rehg J.E., Bush D. \& Ward J.M. 2012. The utility of immunohistochemistry for the identification of hematopoietic and lymphoid cells in normal tissues and interpretation of proliferative and inflammatory lesions of mice and rats. Toxicol. Pathol. 40:345-374.

Ree H.J, Raine L. \& Crowley J.P. 1983. Lectin binding patterns in diffuse large cell lymphoma. Cancer 52:2089-2099.

Rogers K.S. 1997. Transmissible venereal tumor. Comp. Cont. Educ. Pract. Vet. 19(9):1036-1045.

Sandusky G.E., Carlton W.W. \& Wightman K.A. 1987. Diagnostic immunohistochemistry of canine round cell tumors. Vet. Pathol. 24:495-499.

Scott D.W., Miller W.H. \& Griffin C.E. 2001. Neoplastic and non-neoplastic tumors, p.1365-1369. In: Ibid. (Eds), Muller and Kirk's Small Animal Dermatology. 6th ed. W.B. Saunders, Philadelphia.

Sell A.M. \& Costa C.P. 2000. Atividades biológicas das lectinas PHA, WGA, jacalina e artocarpina. Acta Scientiarum 22(2):297-303.

Sticker A. 1904. Transplantables lymphosarkom des Hundes (1904), p.498-502. In: Moulton J.E. (Ed.), Tumors in Domestic Animals. 3rd ed, California University Press, Berkeley.

Swerdlow S.H., Angermeier P.A. \& Hartman A.L. 1988. Intrathymic ontogeny of the T cell receptor associated CD3 (T3) antigen. J. Tech.. Meth. Pathol. 58(4):421-427.

Theilen G.H. \& Madewell B.R. 1987. Clinical applications of cancer chemotherapy: veterinary cancer medicine. 2 nd ed. Lea and, Febiger, Philadelphia, p.183-196.

Vermooten M.I. 1987. Canine transmissible venereal tumor (TVT): a review. J. South Afr. Vet. Assoc. 58:147.

Von Holdt B.M. \& Ostrander E.A. 2006. The singular history of a canine transmissible venereal tumor. Cell 126(11):445-447.

Yang T.J. 1988. Immunobiology of a spontaneously regressive tumor, the canine transmissible venereal sarcoma: a review. Anticancer Res. 8(1): 93-95. 